\title{
Resettlement of Internally Displaced Persons in the North Central Geopolitical Zone of Nigeria
}

\author{
Askederin, F. $\mathrm{M}^{1 *}$, Omole, D. $\mathrm{K}^{2}$, Shonibare. D. $\mathrm{O}^{2}$ \\ ${ }^{1}$ Department of Public Administration, Texila American University, Georgetown, Guyana \\ ${ }^{2}$ Nigerian Educational Research and Development Council, Sheda, Abuja, Nigeria
}

\begin{abstract}
This paper investigated the Humanitarian Crisis in the North Central zone of Nigeria and the resettlement challenges faced by Internally Displaced Persons (IDPs). It was designed to find out the types and causes of Displacement in the zone and determine the readiness of IDPs to return to their original communities before Displacement. The Research was carried out in three states of the North Central Geopolitical Zone, which are Nasarawa, Niger, and the Federal Capital Territory using a total of nine IDP camps. It was conducted using a combination of research designs by applying quantitative and qualitative research methods. Data was collected using three data collection tools which are questionnaires, observation schedule, and focus group discussions schedule. Results revealed that the internally displaced persons found in the North Central geopolitical zone in the states of Nasarawa and the FCT come mostly from the Northeastern states of Borno, Adamawa, and Yobe, and were displaced due to the Boko Haram insurgency. Those living in Niger State come from within Niger and were displaced due to Banditry. Results also revealed that the majority of IDPs live in deplorable conditions within the North Central Geopolitical zone with limited access to food, education, health services, water, sanitation, and hygiene facilities. The Research further revealed that most IDPs are willing to return to their original homes, and their first deciding factor to return is the restoration of security back in their communities, the second factor is their family ties, third is funding to support their return, and then fourth is government legislation that may compel relocation of displaced persons.
\end{abstract}

Keywords: Humanitarian, Insurgency, Internally Displaced Persons, Refugees, Resettlement.

\section{Introduction}

Nigeria is the most populous Country in Africa, with an estimated population of 193 million individuals as at 2016 [1]. The Country comprises of 36 states and the Federal Capital Territory (FCT). It is divided into six geopolitical zones: the North Central, Northwest, Northeast, Southwest, South-South, and the Southeast. Each region comprises 6 states except for the Northwest and Southeast, which have seven and five states, respectively. In the last twelve years, Nigeria has experienced several disasters that led to Displacement in different parts of the Country. As at the end of
2019, there are about 2.6 million people in Nigeria displaced by disasters majorly caused by the insurgency, banditry, and flooding [2].

The United Nations Refugee Commission defined displaced people as persons who have had to leave their homes as a result of a natural, technological, or deliberate event, and include two categories of people; internally displaced people (people who remain in their own countries), and refugees (people who cross international borders) [3]. Displacement is caused by natural disasters like floods, earthquakes, hurricanes, famine and can also be man-made, like conflict, prosecution, and 
development projects. Due to the effect of Displacement, individuals flee their lands, means of livelihood, and leave behind their homes and assets. According to UNHCR, over 70 million people were displaced worldwide as of January 2019 [3]. About 14.6 million people constitute new Internal Displacement across 127 countries between January and June 2020 alone, with disasters responsible for about 9.8 million, while conflict and violence triggered the other 4.8 million displacements [4]. Displacement breaks family and community ties. It forces persons affected to lose their valuables, including documentation which could result to denial of services or means of seeking compensation [5]. In Nigeria, major causes of Displacement include Insurgency, Banditry, and Floods [6].

The concept of Internal Displacement emerged in the early 1990s with no clear definition of what it is. However, it was clear that it needed to be differentiated from the concept of Refugees who are already clearly defined by International Law. While both Refugees and Internally Displaced Persons (IDPs) are displaced persons, a Refugee is one who has crossed an internationally recognized border, while an IDP is a displaced person who remains within his/her country of citizenship or habitual residence. Both groups face several forms of vulnerability due to their inability to access basic services, loss of their properties, and even legal documentation.

Nigeria is in the twelfth year of the Boko Haram insurgency, and the conflict has led to the Displacement of over two million people who currently reside in Internally Displaced Persons (IDP) camps within the Country. The problem of internal Displacement in Nigeria has become a recurrent challenge largely due to the insurgency in the Northeastern part of the Country caused by Boko Haram terrorist. Many citizens from communities in the Northeastern states of Borno, Adamawa, and Yobe have become displaced due to attacks by insurgents, and this has led to the movement of individuals from their homes to settlements and camps within and outside the Country, these people have suffered a great deal losing their livelihood and access to services [79].

Another category of Displacement has emerged in the last few years due to the increased incidence of Banditry in the northcentral and north-western states [10]. Communities in the northwest, north central, and other states of the country have seen an increased incidence of this problem in recent years largely due to desertification and increased unemployment among youths. Over 200,000 people were displaced in Katsina, Sokoto, and Zamfara states between January and August 2019; although a number of them have been returned to their communities, the displaced persons had faced major challenges, which include the loss of properties and livelihood, as well as fear of future attacks [11].

According to 2020 data from the National Emergency Management Agency (NEMA), there are three hundred and seventy-five (375) IDP Camps in the Country holding IDPs, with the north-central states of Niger, Nasarawa, and the FCT having thirty-one (31) camps. This research aims at exploring reasons why many IDPs residing in the camps are yet to return to their original communities even after the security agencies have recovered such communities from the control of insurgents or bandits. The IDPs have continued to live in congested camps with dilapidated infrastructure and poor living conditions. This is especially true for those living in informal camps like the once found in the north-central geopolitical zone, especially the Federal Capital Territory. This Research will provide a framework that is aimed at guiding the government, national and international partners on the strategies to rehabilitate and resettle IDPs. It will identify the main factors that will support resettlement and relocation of IDPs from Camps.

There are two government agencies, and a Federal Ministry that directly carter to the needs of IDPs in Nigeria. These are the National 
Commission for Refugees, Migrants, and Internally Displaced Persons (NCFRMI) and the National Emergency Management Agency (NEMA). In 2019, the Federal Ministry of Humanitarian Affairs, Disaster Management, and Social Development was created to coordinate humanitarian activities, and these agencies fall under its purview. These Agencies and the Ministry provided background information on the plight of IDPs in Nigeria and help support the Research with valuable information on the location and population.

Data collected from locations where resettlement has taken place some years back showed that it came with some challenges. Studies that attempted to explore the issue of resettlement among Nigerian IDPs reveal some concerns from the affected population. Firstly, IDPs feared that people who have returned from the IDP camps prematurely due to coercion or force have suffered financially and materially, and some have become displaced again due to renewed attacks or killing; secondly, many find their homes and local infrastructure completely destroyed, and some who went back said they wish that they never went back due to continuous attacks [12].

The absence of an appropriate legal framework, dearth of reliable statistics, ineffective mechanisms for accountability, and repatriations of IDPs are some of the major challenges affecting the rehabilitation of IDPs in Nigeria [13]. They explained that IDPs find it difficult to return home because they have lost most of their property and often have nothing to return to and, there are no measures for compensation. These are being addressed by the current government, particularly in Borno state, by developing programmes that will consciously encourage IDPs to return to their communities.

Studies that compared the management of IDPs in Nigeria and Cameroun revealed that though Nigeria have more national structures for managing IDPs compared to Cameroun, which depends heavily on the support of International Organizations, the issue of limited funding among Nigerian officials saddled with the responsibilities to provide for IDPs is a major challenge [14]. The study showed that although they lack a national structure, Cameroun has managed to reintegrate all IDPs in the Bakassi region while Nigeria is yet to reintegrate its IDP population. This may be due to the absence of a systematic framework to ensure that resettlement is done effectively. Another challenge is the dearth of studies or recommendations to the effective return of Nigerian IDPs to their communities or settling them in other locations out of camps. This Research will attempt to close some of these gaps by identifying major challenges that prevent the return of IDPs.

\section{Research Objectives}

This Research will be conducted among the IDP population living in camps within the northcentral geopolitical zone where the activities of most International and National Humanitarian Organizations is not focused. Little is known about this population of IDPs due to the minimal activities of International Organizations in this location. Since most IDPs are considered to come from far locations to their respective camps, it is important to understand their current situations and plans if any, for returning home.

The main focus of this study is to unveil the nature of the Humanitarian Crisis in the North Central Geopolitical zone of Nigeria and how to promote the resettlement of IDPs. The following are specific objectives:

1. To find out the causes of Displacement in Nigeria.

2. To determine how far IDP camps are from the original homes of the IDPs.

3. To determine the types of Displacement in Nigeria.

4. To estimate the average population in surveyed camps.

5. To identify amenities that are available in the camps being surveyed.

6. To determine readiness of IDPs to return to their communities. 
7. To list the challenges anticipated by IDPs in returning to their communities.

8. To list factors that will promote the quick return of IDPs to their communities.

\section{Research Question}

The following research questions are populated to sharpen the investigation.

1. Where are IDP camps located?

2. How far are the IDPs from the original homes?

3. What is the population of IDPs in surveyed camps?

4. What are the causes of Displacement in Nigeria?

5. What are the types of Displacement in Nigeria?

6. What type of shelter do IDPs have within the camps?

7. Is the available shelter adequate?

8. Are the shelters overcrowded?

9. How do IDPs access food within or around the camps

10. Are there Water Sanitation and Hygiene (WASH) facilities available at the camps?

11. Are there Health facilities available at the camps?

12. Are there educational facilities available at the camps?

13. Do the IDPs have access to employment opportunities?

14. Is there security in the IDP camps?

15. What population of IDPs are ready to return to their communities, and what population wants to be resettled in other communities?

16. What are the challenges of return anticipated by IDPs?

\section{Significance of the Study}

The Research is expected to provide knowledge for a better understanding of why IDPs remain in Camps even after their communities have been liberated from the Boko Haram Terrorist, Banditry, Floods, and or Communal Clashes. It will provide stakeholders with factors that can support the resettlement of
IDPs in Nigeria and contribute towards the effort to resettle over two million IDPs located across different states of the Country. Finally, it will identify factors that guide the return of the populations and present these findings in a structured manner to policymakers.

\section{Research Methods}

The Research looks at the issues of resettlement with regards to Internally Displaced Persons in the North Central Geopolitical Zone of Nigeria. Internal Displacement has become an ongoing issue since 2009 and has remained a national issue with an estimated population of two million persons living in IDP camps [15].

Currently, there is the dearth of Research on internally displaced persons in the Country. Hence studying the population requires preengagement with the affected population to determine the issues/themes that contribute to the problem. It required intensive review of data available in the public domain on IDPs, which came mainly from programme implementation in the Country. This includes the number of camps, their location, household size, number of individuals living in the camps as well as any other relevant information that is available pre visitation of the camps. Pre-engagement was conducted with leaders of the camps to determine common themes.

This helped to finalize the design of a questionnaire to have a structured instrument that will be administered and guide the determination of what to look out for during data collection in sampled camps. The Research explored the problem using three approaches within the North Central geopolitical zone of Nigeria. This constituted of structured interviews, focus group discussions, and observation.

\section{Research Design}

The Research used descriptive design by applying a mix method of Research with quantitative and qualitative approaches. It applied three research methodologies which are: 


\section{Focus Group Discussions}

This method of data collection involves interviews or discussions with several people at the same time on a specific topic or issue [16]. It entailed discussions with different subsets of the population in groups, led by a research assistant that moderated or facilitated the discussion to observe how group members respond to each other's views and determine where there is a collective understanding or opinion about an issue or if opinions vary vastly. This discussion took place among individuals within the camp in groups of 8 to 12. It explored various topics such as shelter, security, health, nutrition, and other issues that affect the lives of IDPs in camps and how this affects their decisions regarding resettlement.

\section{Structured Interviews}

This is a type of research interview that is commonly employed in survey research and involves the administration of an interview by an interviewer. The goal is to ensure respondents are interviewed in a standardized way in efforts to reduce variation and promote standardization in the method questions are asked and recorded [16]. It involved the administration of the questionnaire at the individual level to sampled IDPs that give consent to the research assistant. Sampled number of IDPs were interviewed in each camp.

\section{Observation}

This is an underused method of data collection in Research but is valuable in understanding some phenomena like living conditions, type of shelter, environment, and sanitation within a locality. During the Research, an observation tool was administered at each camp to identify issues around the type of shelter which IDPs use, availability of water, sanitation, and hygiene facilities, living conditions, the safety of the environment, population and overcrowding in the camps. One observation tool was administered per IDP camp visited in every state. The research assistant asked IDPs to show them where they sleep, their toilet facilities, drinking water, and how they carry out other basic activities. The research assistant then recorded this in the observation schedule.

\section{Target Population/ Sample Frame}

The population for this study are IDPs living in IDP camps and/or camp like structures in the North Central region of Nigeria. There are six states in the North Central geopolitical zone of the Country, which are Benue, Nasarawa, Niger, Kwara, Plateau, and the FCT. According to data collected from NEMA, the population of IDPs in the North Central geopolitical zone of Nigeria is 30,165 individuals living in 31 IDP camps in three states of the region. Based on the data received in these states, there are seven IDP camps in Niger, nine in Nasarawa, and fifteen in the FCT.

Camps in these 3 states will be surveyed, and the IDPs in the camps will form the population for the survey. The Federal Capital Territory is of particular interest since it is the capital city of Nigeria and one of the major locations of settlement for many citizens that are not even displaced. All individuals living within the sampled IDP camps were considered for the Research.

\section{Sample and Sampling Technique/Design}

The first level of sampling was to deploy a stratified random sampling technique to include all types of camps in the three states. While the three states do not have the same number of IDP camps, efforts was made to visit at least onethird of the camps in each state to get a good representation of happenings in the various locations. This comes up to about ten camps, made up of five camps in the FCT, three camps in Nasarawa, and two camps in Niger State. The second step is purposive sampling to select individuals within these camps for an interview. The third step was to administer the questionnaire among a representative sample of the population in each of the sampled camps. Below is the sampling procedure: 
1. Three states in the North Central zone were purposefully sampled because they have IDPs.

2. From each state, one third of the camps were selected. Out of the total thirty-one camps, ten camps were sampled for the Research.

3. In each camp, three instruments of data collection were applied.

\section{Structured Interview}

where stratified sampling was applied to provide a good representation of all individuals in the camps. This included different categories of individuals, including leaders, men, women, and youth. The sample size was determined based on $95 \%$ Confidence Level and 5\% Confidence Interval. Considering a population of 30,165 individuals living in the camps, the sample size for the survey was 380 individuals. These individuals were interviewed, and they included Men, Women, and Youth.

\section{Focus Group Discussion}

Here, a group of 8 to 12 persons were interviewed in each camp. One focus group discussion was conducted in each camp which totals to 10 focus group discussions to be held during the Research.

\section{Observation}

Here, an observation guide was used to inspect some phenomena's in each camp. This came up to ten observation tools to be administered across ten camps that were sampled.

\section{Procedure for Data Collection}

Data was collected onsite by trained research assistants who interviewed the sampled population in their respective locations. This was conducted through a face-to-face interview.

The interview was estimated to be completed in 7 to 10 minutes; therefore, the time of interview commencement and conclusion was recorded on the interview schedule for quality checks.

\section{Instrumentation}

Three instruments were used to collect data for the Research.

1. Structured Interview Schedule

2. Focus Group Discussion Schedule

3. Observation Schedule

\section{Research Approach / Data Analysis/ Procedure}

There are two approaches to Research which are inductive and deductive research approach. The deductive approach starts with a theory and then collects data to test the theory to determine if it holds on to a given circumstance, while the inductive approach starts with collecting data in an attempt to develop a theory [17]. The deductive approach sets out to test an already established theory, while in the inductive approach, the theory is the outcome of Research. This Research adopted an inductive research approach where data is collected from IDP camps and then analyzed in an attempt to develop a theory that will guide future efforts at resettlement of displaced people living in camps. This approach is chosen because there are no clearly defined theories in the field of IDP resettlement to explain what factors lead to the decision of a person displaced by conflict or natural disaster to return home. The inductive approach will help us establish some theory, at least in the context of Nigeria, that may be applicable in other parts of Sub-Saharan Africa.

The inductive analysis will be deployed to determine important patterns and themes to confirm findings from the data collected. Data will be analyzed using simple statistical tools to determine inter-relationships in responses.

\section{Results}

The results are hereby presented with the research question that each provides an answer to:

1. Where are IDP camps located?

2. How far are the IDPs from the original homes? 
3. What is the population of IDPs in surveyed camps?

A total of 310 Internally Displaced Persons were interviewed during data collection on the field, out of which 173 IDPs were living in the Federal Capital Territory (FCT), 52 IDPs were living in Niger State, and 85 IDPs interviewed were living in Nasarawa states of the North Central Geopolitical Zone. These individuals are spread across four Local Government Areas
(LGA) of the various states. The IDP Camps were located in different cities and villages within the three states. A total of nine locations where IDP camps are found was visited by the data collection team. The tenth IDP camp was found to be closed on the visit by the data collection team, and all the IDPs living there were no longer in the location. Table 1 shows the distribution of the IDPs by State, their location, and the number interviewed in that location.

Table 1. Frequency and Percentage distribution of IDPs by State, Local Government Area and Villages in the North Central region where IDP Camps are located

\begin{tabular}{|l|l|l|l|l|}
\hline State & LGA & Camp & Frequency & Percent \\
\hline FCT & AMAC & Waru & 32 & 10.3 \\
\hline FCT & AMAC & Durumi & 25 & 8.1 \\
\hline FCT & AMAC & Yimitu/Kabusa & 51 & 16.5 \\
\hline FCT & AMAC & Wassa & 65 & 21 \\
\hline Niger & Rafi & Kagara & 47 & 15.2 \\
\hline Niger & Shirro & Shirro & 6 & 1.9 \\
\hline Nasarawa & Karu & Gurku & 25 & 8.1 \\
\hline Nasarawa & Karu & Koso & 21 & 6.8 \\
\hline Nasarawa & Karu & Kugwaru & 38 & 12.3 \\
\hline Total & & $\mathbf{3 1 0}$ & $\mathbf{1 0 0}$ \\
\hline
\end{tabular}

Data collected during focus group discussions on the number of IDPs in the camps indicates that a total of 19,208 individuals are living in the nine IDP camps. Most IDPs in the North Central Geopolitical zone come from the Northeast states of Borno, Adamawa, and Yobe. IDPs in four (4) of the camps totaling 10,597 individuals all come from Borno State, while those in three camps (2830) are from the three states of Borno, Adamawa, and Yobe. IDPs found in the two camps in Niger state (281) are from within Niger state and were displaced as a result of Banditry and Kidnapping.

Table 2. Population of IDPs and their states of Origin

\begin{tabular}{|l|l|l|l|}
\hline State & Number of Individuals & Number of IDP Camps & Percent \\
\hline Borno & 10597 & 4 & 55.2 \\
\hline Borno, Yobe and Adamawa & 2830 & 1 & 14.7 \\
\hline Borno and Adamawa & 5500 & 2 & 28.6 \\
\hline Niger, Madaka & 281 & 2 & 1.5 \\
\hline Total & $\mathbf{1 9 2 0 8}$ & $\mathbf{9}$ & $\mathbf{1 0 0 . 0}$ \\
\hline
\end{tabular}

4. What are the causes of Displacement in Nigeria?

5. What are the types of Displacement in Nigeria?
The causes of Displacement according to IDPs interviewed in the North Central Geopolitical Zone are shown in Table 3 below. The Data reveals that the reason for Displacement for the majority of IDPs 
interviewed was the Boko Haram insurgency, and this is closely followed by Insecurity, Banditry, and Kidnapping. The table also reveals that four of the individuals interviewed came to the Camp not as a result of any displacement, while forty-five of the sampled respondents refused to give a reason for their Displacement.

Table 3. Causes of Displacement among Internally Displaced Person found in the North Central Region of Nigeria

\begin{tabular}{|l|l|l|}
\hline Causes of Displacement & Frequency & Percent \\
\hline Banditry & 13 & 4.2 \\
\hline Kidnapping & 4 & 1.3 \\
\hline Banditry/kidnapping & 26 & 8.4 \\
\hline Boko Haram & 208 & 67.1 \\
\hline Insecurity & 10 & 3.2 \\
\hline None & 4 & 1.3 \\
\hline Total & 265 & 85.5 \\
\hline Missing & 45 & 14.5 \\
\hline Total & $\mathbf{3 1 0}$ & $\mathbf{1 0 0 . 0}$ \\
\hline
\end{tabular}

Displacement results in hardship for the individuals affected as well as their families. Some basic services like Shelter, Food, Water, Sanitation, Hygiene, Health, Education, and Security services may no longer be available to the individual and his/her family. Sometimes these basic services are not sufficient even when they are made available.

6. What type of shelter do IDPs have within the camps?

7. Is the available shelter adequate?

8. Are the shelters overcrowded?

Shelter is one of the basic facilities required by a displaced person. The majority of the IDPs about $44.4 \%$, revealed that they rent shelter from host communities, while $22.2 \%$ said they set up tents in open spaces to stay. In one IDP Camp, Government has provided resettlement estate for the IDPs, while in another location, the IDPs are building their own shelter. The type of shelter used by IDPs range from stick houses to mud houses and tents.

The number of IDPs that sleep in a unit of shelter varies, depending on the Camp. While $26.7 \%$ of the IDP Camps indicated that up to 19 individuals sleep per housing unit in their Camp, $24.4 \%$ indicated that less than or equal to 8 individuals stay in a housing unit, and 20.2\% indicated that 15 individuals sleep in a housing unit.

9. How do IDPs access food within or around the camps?

$55.5 \%$ of IDPs interviewed access food through farming, while $13.9 \%$ get their food from well-wishers or donors. Others did not give specific details on how they access food. Another factor assessed by the Research is how many times a day the IDP eats. Here most IDPs, about $34.5 \%$, indicated that they ate two times a day, while $29 \%$ indicated that they ate three times a day, and about $18.7 \%$ said they ate once a day.

10. Are there Water Sanitation and Hygiene (WASH) facilities available at the camps?

One of the basic services for survival by an individual is water. Various IDP camps visited were assessed for the availability of water, sanitation, and hygiene facilities. Data collected revealed that most of the Camps get water from a Borehole which was constructed at the Camp by Government, Donor, or Private Individual. IDPs in one of the Camps said they access water from the stream. This is shown in Table 4 below. 
Table 4. Water Source at the IDP Camp

\begin{tabular}{|l|l|l|l|}
\hline Availability of water at the camps & Number of Camps & Number of IDPs & Percent \\
\hline Borehole & 5 & 14727 & 76.7 \\
\hline Stream & 1 & 280 & 1.5 \\
\hline Buy from Borehole & 2 & 4200 & 21.9 \\
\hline None & 1 & 1 & .0 \\
\hline Total & 9 & 19208 & 100.0 \\
\hline
\end{tabular}

Table 5 below shows the types of Toilet Facilities available at the IDP Camp $66.7 \%$ of the IDP camps have no toilet facilities. These individuals use the bush. Only one out of nine
IDP camps has a toilet facility. In four of the nine camps, men and women share the same toilet facility, as indicated in Table 6.

Table 5. Type of Toilet Facility in the Camp

\begin{tabular}{|l|l|l|l|}
\hline Type & Number of Camps & Number of IDPs Affected & Percent \\
\hline Bush & $\mathbf{6}$ & 16307 & 84.9 \\
\hline WC & $\mathbf{1}$ & 2000 & 10.4 \\
\hline Bush/Pit & $\mathbf{2}$ & 900 & 4.7 \\
\hline Total & 9 & 19207 & 100.0 \\
\hline
\end{tabular}

Table 6. Do Men and Women use the same Toilet Facility?

\begin{tabular}{|l|l|l|}
\hline Type & Number of Camps & Percent \\
\hline Yes, Men and Women use the same Toilet Facility & 4 & 44.4 \\
\hline No, Men and women do not use the same Toilet Facility & 5 & 55.6 \\
\hline Total & 9 & 100.0 \\
\hline
\end{tabular}

11. Are there Health facilities available at the camps?

The third basic service investigated by this Research is the Internally Displaced Person's access to Health Services. $76.7 \%$ of the IDPs said they access health services through a clinic within the Camp, while $23.3 \%$ said they have no access. One of the camps has a clinic, while in another camp, the IDPs said they access health services from a nearby Government Health Centre. When the IDPs were asked how they get treatment when sick, $35.5 \%$ said they get services from a clinic within the IDP Camp, about $25.8 \%$ said they go to the Pharmacy/Chemist, while $20.3 \%$ go to a Hospital/Clinic. About $4.8 \%$ go to a local healer or native doctor.
12. Are there educational facilities available at the camps?

Data collected from the Research shows that many IDPs live within family structures and have dependents that are school age. Table 7 reveals that $60 \%$ of IDPs have a school located within or around their premise while $40 \%$ of IDPs do not have schools near them. Table 8 shows that about $68.1 \%$ of IDPs have school-age children, however, only $48.7 \%$ of the schoolaged children go to school. 58.9\% of IDP dependents that go to school attend public schools, while about $10.3 \%$ attend a school within the IDP camp, and $9.7 \%$ go to Private school as shown in Table 9. 
Table 7. Is there school within the IDP Camp?

\begin{tabular}{|l|l|l|l|}
\hline Availability of School within IDP Camps & Frequency & Percent & Population \\
\hline IDPs that have access to a school within their camp & 4 & 60.0 & 11521 \\
\hline IDPs with no access to a school within their camp & 5 & 40.0 & 7687 \\
\hline Total & 9 & 100.0 & 19208 \\
\hline
\end{tabular}

Table 8. IDPs with School Aged Children that Go to School

\begin{tabular}{|l|l|l|l|l|l|}
\hline IDPs with school aged children & Frequency & Percent & \multicolumn{3}{|c|}{ Do they go to school } \\
\hline Yes & 211 & 68.1 & Yes & 151 & $48.7 \%$ \\
\hline No & 78 & 25.2 & No & 60 & $19.4 \%$ \\
\hline Total & 289 & 93.2 & Total & 211 & $68.1 \%$ \\
\hline
\end{tabular}

Table 9. If your Answer to Table 8 is Yes, Which Type of School do your Dependents Attend?

\begin{tabular}{|l|l|l|}
\hline Type & Frequency & Percent \\
\hline Public & 89 & 28.7 \\
\hline Private & 30 & 9.7 \\
\hline Within the IDP Camp & 32 & 10.3 \\
\hline Total & 151 & 48.7 \\
\hline
\end{tabular}

13. Do the IDPs have access to employment opportunities?

Access to employment opportunities will reduce the vulnerability of an Internally Displaced Person and provide them with a means to support their family. Data collected shows that $48.5 \%$ of IDPs in the camps surveyed are currently employed, while $51.5 \%$ are unemployed. The type of employment engaged by those IDPs that are employed shows $29 \%$ of the employed IDP are working in the farming sector, this is closely followed by Tailors $(5.5 \%)$, then Labourers (2.9\%) and then Drivers (1.9\%).

14. Is there security in the IDP camps?

Insecurity is identified as one of the biggest challenges currently faced in Nigeria. The majority of IDP camps assess $(44.5 \%)$ indicated that security in their Camp is Poor, while $22.2 \%$ said their Camps are secured. Another 22.2\% said they have no security while $11.1 \%$ indicated they have satisfactory security provision.

15. What population of IDPs are ready to return to their communities, and what population want to be resettled in other communities?

16. What are the challenges of return anticipated by IDPs?
Most IDPs engaged with during the focus group discussion revealed that they are willing to relocate back to their homes/communities before they were displaced. The major factor in the decision to relocate is the restoration of peace in their community as revealed by $77.7 \%$ of IDPs.

Focus group discussion response data on relocation was correlated by data collected from a questionnaire administered to individuals in the Camps. Table 10 shows that $54.8 \%$ of IDPs Strongly Disagreed or Disagreed with the notion to remain in the IDP camps. $80.3 \%$ are willing to return to their original homes within 6 months if the reason for their Displacement is addressed.

The four factors assess that influence the IDPs decision to return home are security, funds, government legislation, and family ties. This is shown in Table 10 above. Data collected revealed that the major factor in the decision of IDPs to return to their original community of inhabitance before Displacement is the restoration of security at $79 \%$, followed by family ties at $63.4 \%$, then funds to support relocation at $61.3 \%$ then finally, Government Legislation at $55.2 \%$. 
Table 10. Factors that Influence Relocation Decision by an IDP

\begin{tabular}{|c|c|c|c|c|c|c|}
\hline \multirow{2}{*}{\multicolumn{2}{|c|}{ Decision regarding relocation from the IDP Camp }} & \multirow{2}{*}{\multicolumn{5}{|c|}{ Level of Agreement with the following statements regarding relocation }} \\
\hline & & & & & & \\
\hline Will the IDP prefer to settle in the current location & Frequency & $\begin{array}{l}\text { Strongly Disagree } \\
76 \\
\end{array}$ & \begin{tabular}{|l|} 
Disagree \\
94 \\
\end{tabular} & Agree & $\begin{array}{l}\text { Strongly Agree } \\
43\end{array}$ & $\begin{array}{l}\text { Total } \\
261 \\
\end{array}$ \\
\hline & Percentage & 24.5 & 30.3 & 15.5 & 13.9 & 84.2 \\
\hline \multirow{2}{*}{$\begin{array}{l}\text { If the reason for the Displacement is addressed, the IDP is } \\
\text { willing to go back to within } 3 \text { to } 6 \text { months }\end{array}$} & Frequency & 3 & 1 & 59 & 190 & 253 \\
\hline & Percentage & 1 & 0.3 & 19 & 61.3 & 81.6 \\
\hline \multirow{2}{*}{$\begin{array}{l}\text { Major factor for my relocation is the restoration of Security } \\
\text { in my home }\end{array}$} & Frequency & 2 & 10 & 44 & 201 & 257 \\
\hline & Percentage & 0.6 & 3.2 & 14.2 & 64.8 & 82.9 \\
\hline \multirow{2}{*}{$\begin{array}{l}\text { Major factor for my relocation is the availability of funds to } \\
\text { resettle }\end{array}$} & Frequency & 3 & 13 & 98 & 92 & 206 \\
\hline & Percentage & 1 & 4.2 & 31.6 & 29.7 & 66.5 \\
\hline \multirow{2}{*}{$\begin{array}{l}\text { Major factor for my relocation is the decision by my family } \\
\text { members that we need to go back home }\end{array}$} & Frequency & 14 & 64 & 79 & 56 & 213 \\
\hline & Percentage & 4.5 & 20.6 & 25.5 & 18.1 & 68.7 \\
\hline \multirow{2}{*}{$\begin{array}{l}\text { Major factor for my relocation is the Government Legislation } \\
\text { that all IDPs must return home }\end{array}$} & Frequency & 16 & 34 & 92 & 79 & 221 \\
\hline & Percentage & 5.2 & 11 & 29.7 & 25.5 & 71.3 \\
\hline
\end{tabular}




\section{Discussion}

Three states out of the six states in the North Central Geopolitical Zone were purposefully sampled for this Research, with ten camps scheduled for a visit. Eventually, nine IDP camps were visited as the last IDP Camp has been closed, and the IDP population no longer lived there.

Data collected revealed that the majority of IDPs in the North Central states of Nasarawa and the FCT come from Borno, Adamawa, and the Yobe States, which are in the Northeast Geopolitical Zone of Nigeria. This indicates that most IDPs have travelled a minimum of $850 \mathrm{~km}$ to about $1000 \mathrm{~km}$ from their communities/states in the Northeast to come to the North Central Geopolitical Zone. IDPs in the two camps in Shiroro and Rafi Local Government Areas of Niger state are from Madaka, within Niger. This indicates that they are displaced within their own state and have travelled a distance of $35 \mathrm{~km}$ to $200 \mathrm{~km}$ to escape Banditry and Kidnapping within their states. This is a common phenomena for IDPs across the world, as many of them travel several kilometers to escape their homes in times of disasters such as insecurity, banditry, or natural disasters like flooding [18].

The Federal Capital Territory (FCT) had the highest number of IDPs, with 55.8\% of IDPs interviewed living in the FCT. This is followed by Nasarawa State with $27.4 \%$ of the population and then Niger State with $16.8 \%$. Internally Displaced Camps visited are located in four LGAs within the three states and found in nine different communities.

The Boko Haram Insurgency/Insecurity is the biggest cause of Displacement among the Internally Displaced Persons interviewed, as indicated by $70.3 \%$ of IDPs living in the North Central Geopolitical Zone, who stated it as their reason for Displacement. This data is supported by various studies of Internally Displaced Persons in Nigeria, such as in the Research by [19]. This reason is closely followed by Banditry and Kidnapping at $13.9 \%$, this cause of Displacement is closely becoming a sauce of major concern as indicated in studies conducted by [20].

Data collected from the Camp leadership reveals that about 19,208 households live in the Camp, and $81 \%$ of them have dependents. The information varies from data collected from the National Emergency Management Agency (NEMA) 2019 data on IDPs in Niger, Nasarawa, and the FCT. Data collected from the field shows a higher number of IDPs by about $10 \%$ than what is available in the records of the Agency. This can be explained by the fact that the data from NEMA is as of 2019, so there is a need for the Agency to collect fresh data especially in the face of increasing insecurity nationally.

Basic services like shelter, water, food, health, and education services are necessary for an individual or household's survival. Access to these services are contributing factors to whether individuals are willing to return to their communities of origin or prefer their newfound homes if they are getting better services at the Camps. Data collected reveals that most services are non-existent or inadequate at the IDP camps.

In $44 \%$ of the Camps, shelter is rented by IDPs, while 33\% use Tents or Open spaces and $11 \%$ use Government resettlement estate as shelter. The type of Shelter is mostly Stick House (44.4\%), while others are mud houses and Open Space.

Farming is the most common strategy to access food by most IDP, as $55.5 \%$ of those interviewed indicated it as their way of feeding. $13.9 \%$ get their food from well-wishers or donations, which shows that there is some level of support offered to the IDPs by outsiders.

Availability of water was considerable in most IDP Camps visited as the majority had access to borehole facilities which was provided by various actors such as Donors, Government, Private Individuals, and even the IDPs themselves. Sanitation is carried out monthly in one of the Camp, and this was evident by the cleanliness of the environment in the camp. However, other camps did not make a conscious effort towards sanitation of the environment. 
Toilet Facilities are non-existent or inadequate in most of the camps. This is evident from information collected that only one camp out of the nine surveyed had access to WC. In 4 out of 9 IDP camps surveyed, men and women share the same toilet facility.

Five out of the nine IDP camps have a Health Centre within the camp where they access services. 35.5\% IDPs surveyed said they access medical treatment within the health facility at their Camp, 20.3\% said they go to Hospital, and $25.8 \%$ go to Pharmacy, while $4.8 \%$ go to local Healer/Native Doctors. This reveals the major gap in access to health services by the IDPs.

Four out of nine IDP Camps have a school within the camp, and 68\% of IDPs have schoolaged Children, out of which $71.6 \%$ send their children to school while $28.4 \%$ do not send their children to school. Among those with children in school, $58.9 \%$ of the IDP children access educational services from Public Schools.

These data show that IDPs have received some level of support from well-wishers, Philanthropist, Non-governmental organizations in the areas of Water, food, health care, and education. They also have some level of support from the Government in terms of access to Public Health Facilities and Educational services in the community.

Employment is a major challenge for most IDPs, as the majority of them used to be farmers and have now lost their farmlands due to insecurity. The research revealed that $49 \%$ of IDPs are unemployed, while $46.1 \%$ are employed in part-time jobs. The majority of the IDPs, 29\%, are still farmers, even though they do not have their own farmlands. About 5.5\% are Tailors, $2.9 \%$ are Laborers, and others are Carpenters, Plumbers, Drivers, and other menial jobs.

Security remains a major challenge in the Camps, although most IDPs indicate that there is better security at the Camp than where they are coming from. Six out of the nine IDP Camps have security posts, and the majority of the camps have vigilante groups. Some of the camps have access to police or the military. Over $40 \%$ of IDPs said they are not aware of any security breach in their Camp, while another $40 \%$ said they have heard of security breaches within their camps. However, they indicated they feel more secured here at the IDP Camps than where they came from in the Northeast.

The data reveals that security is provided at two levels, the government that provides the IDPs with some level of support in the area of security, and their own local vigilante groups. The majority of the IDP Camps have a security post and have formed vigilante groups to defend themselves.

$100 \%$ of the IDP Camps surveyed said their members have a good relationship with the host community. This may be a factor in their decision to return home or resettle in their current location. $55.6 \%$ of IDPs indicated their interest to relocate back home if security is restored, while $44.4 \%$ do not want to go back to their original communities before Displacement. After the further engagement, $44.4 \%$ said they are not willing to return because the factors that resulted in their Displacement have not been address. This is primarily insecurity as revealed by $77.7 \%$ IDPs. Most IDPs $65.1 \%$ Strongly Disagreed or Disagreed with the notion to remain in the IDP camps. This was confirmed by the willingness of more than $80 \%$ to return to their original homes within 6 months if the reason for their Displacement is addressed. Four factors used to measure the determining factor for resettlement were security, funds, government legislation, and family ties. Security was revealed as the major factor, with $79 \%$ of IDPs saying it is the main deciding factor for their return to their communities. Family ties were cited by $63.4 \%$ of the IDPs, which was then followed by funding and then finally Government Legislation.

\section{Conclusion and Recommendation}

In conclusion, this study reveals that Internally Displaced Persons from the Northeast Geopolitical Zone are found in the North Central 
States of Nasarawa and the Federal Capital Territory in significant numbers. IDPs met in Niger state are mostly from Madaka, within Niger State. Most IDPs have settled well within the community, and they all have a cordial relationship with their host communities.

Major finding is that more than $50 \%$ of the IDPs are willing and ready to return to their original communities provided the challenges of insecurity that led to their Displacement has been addressed. Out of the four factors assessed as influencers of IDPS decision to return to their communities, Security was found to be the greatest influencer of the IDPs decision. This was followed by family ties, then the availability of funds, and finally government legislation. The majority are willing to return within the next 3 to

\section{Reference}

[1] National Population Commission, 2016, Date of access: 05-10-2020.

file://C:/Users/fatiy/Downloads/Demographic\%20S tatistics\%20Bulletin\%202017\%20(2).pdf.

[2] IDMC Report, 2021, Date of access: 28-03-2021. https://www.internal-displacement.org/globalreport/grid2021/.

[3] Norwegian Refugee Council, 2019, Report on 70.8-million-displaced-people, Date of access: 3103-2021. https://www.nrc.no/shorthand/fr/70.8million-displaced-people/index.html.

[4] IDMC, 2020, Nigeria IDMC, Date of access: 0102-2021.

https://www.internal-displacement.org/globalreport/grid2020/.

[5] Mooney, E., 2005, Refugee Survey Quarterly, Vol.24, Issue 3., Date of access: 10-04-2021. https://doc.rero.ch/record/299905/files/hdi049.pdf.

[6] IDMC Report, 2018, Date access: 03-04-2021. https://www.internal-

displacement.org/features/nigeria-internaldisplacement-crisis-conflict-floods

[7] Adeyeye, A., 2013, Identity conflict, terror, and the Nigerian state: Between fragility and failure, Journal of Sustainable Development in Africa, 15, 116-129.
6 months if this issue is resolved. It is therefore recommended that security be considered as the number one factor to be addressed to facilitate the relocation of IDPs.

\section{Acknowledgements}

I wish to thank God Almighty, my family, and teachers for supporting me to conduct this Research.

I wish to appreciate the participants that provided us feedback which made this Research possible. This Research was successful because you have all supported my work.

\section{Conflict of Interest}

There is no conflict of interest in this Research.

[8] Imasuen, E., 2015, Insurgency and the humanitarian crises in the Northern Nigeria: The case of Boko Haram, African Journal of Political Science, and International Relations, 9(7), 284 - 296.

[9] Joshua, S., \& Olanrewaju, F. O., 2016, The impacts of terrorism on education: The North-eastern Nigeria's experience, JIPAD: Journal of International Politics and Development, 14, 59-74. [10]NCFRMI, 2019, Persons of Concern Report, Date of accessed: 27-04-2020. https://ncfrmi.gov.ng/. [11]UNHCR., 2019, Nigeria Key Message update, September 2019, Date of access: 05-10-2020. https://reliefweb.int/report/nigeria/nigeria-keymessage-update-september-2019.

[12] Oluwole, I. O., Eme, O. I., and Aloh, R., 2017, Rehabilitation of Internally Displaced Persons in the Nigeria Northeast: challenges and prospects, Social Scientia, Vol 2, No 23.

[13] OXFAM, 2016, Africa's Fastest Growing Displacement Crisis, Date access 03-03-2020. https://www-cdn.oxfam.org/s3fs-

public/file_attachments/bn-lake-chad-refugees-idps190816-en.pdf.

[14] Osagioduwa, E. and Oluwakorede, O. T., 2016, Management of Internally Displaced Persons in Africa: comparing Nigeria and Cameroun, Afrrev, 
Vol $10 \quad(1), \quad$ No $40 \quad$ Doi: http://dx.doi.org/10.4314/afrrev.v10i1.15n.

[15]UNOCHA, 2020, Nigeria: Humanitarian Response Plan, Date of access: 02-10-2020. https://www.humanitarianresponse.info/en/operation s/nigeria/humanitarian-response-plan.

[16]Bryman, A., Becker, S., and Sempik, J., 2008, Quality Criteria for Quantitative, Qualitative and Mixed Methods Research: The view from Social Policy, International Journal of Social Research Methodology, 11:261 - 276.

[17]Bryman, A., 2012, Social research methods (Oxford, U.K.: Oxford University Press).
[18]UNHCR, 1992, Analytical Report of the Secretary-General on Internally Displaced Persons, UN Doc. E/CN.4/1992/23 (14 February 1992), para. 17.

[19] Olanrewaju, F. A., Olanrewaju, A., Omotoso, F., Alabi, J. O., Amoo, E., Loromeke, E., and Ajayi, L.A., 2019, Insurgency and the Invisible Displaced Population in Nigeria: A situational Analysis, SAGE, DOI: $10.1177 / 2158244019846207$.

[20] Okoli, C. A., 2019, What can be done to fight Rural Banditry in Nigeria. Date of access: 05-032021. https://reliefweb.int/report/nigeria/what-canbe-done-fight-rural-banditry-northern-nigeria. 